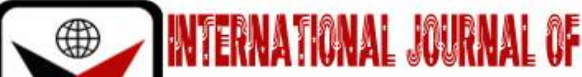

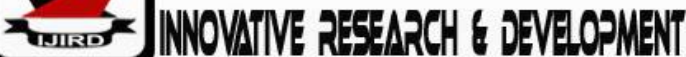

ISSN 2278 - 0211 (Online)

\section{The Influence of the Risk Transfer on Project Success in Access to Finance Rwanda}

Theotime Rutabubura
Student, Department of Entrepreneurship, Technology, Leadership and Management,
(ETLM), Jomo Kenyatta University of Agriculture and Technology, Kenya
Dr. Patrick Mulyungi
Lecturer, Department of Entrepreneurship, Technology, Leadership and Management,
(ETLM), Jomo Kenyatta University of Agriculture and Technology,

\begin{abstract}
:
The primary objective is to access the transfer of uncertainty those are responsible behind a success of a project. Access to Finance Rwanda (AFR) has aims to make itself grand success. These initiatives also consider the staff regarding the success of AFR project. Musanze district has been selected as the area for conducting the study. It has been revealed through this study is that risk transfer negatively affects project success. Conclusive research design has been selected for this study. Sampling techniques was simple random sampling techniques as data collection tools were documentary review for secondary data where questionnaires and interview were used as primary data. The sample size is of 169 from a population of 291 using Slovin's formula. The study found that when ensuring staff is not take into consideration the project cannot become successful hence leading to failure. The research found out that once the equipment and premises are not insured it leads to the project. The study recommended that access to finance Rwanda have to continue and emphasize on insuring its personnel. Premises and equipment are important because of the future AFR project implementation.
\end{abstract}

Keywords: Risk transfer, finance, risk management

\section{Introduction}

For sectors like, agriculture or firming, uncertainty is one of the common problems. The fear of loss, the fear of hampered productions is very common issues. Associated parties are always getting hugely impacted though this. As per PMI most of the projects are uncertain by nature. Many assumptions, constraints continuously affect them. This is motivation behind the introduction of project risk management methods. Throughout the life-cycle of projects these are important to maintain and follow (Addison, 2012). In the agriculture sector, most of the projects failed as they sometimes though that projects are similar to each other. Sometimes, although the area or problems are same, but analysis, contingencies, risks are entirely different. Hence risk identification, analysis, mitigation will need different treatment. Every project aims to get executed in a less risky environment (Akintole A.S 2017). Project managers are always in pressure, to minimize the chance of failure. This is the reason people working their supervisions always pressurized to work hard and to eliminate the pressure as much as they can. Popularly, among many dimensions, time, quality and risk are the three dimensions to work seriously. Kerzner (2001) introduced two more factors that have the potential to become important factors. The one factors is risk management both effectively and efficiently and the second one is the project must be accepted by the customers.

It is an acceptable that the success of any project is largely associated by the methods and processes associated with the risk management process. Through-out the life cycle of the project they are affecting the success of the projects. Risk elimination has direct influence to the increment of the performance of the project. The primary aim is to investigate the impact of risk transfer methods on project performance.

A case study of RSSB multi-storey has been considered. The world has experienced failure of many projects both big and small due project caressing that led to increase in project time and costs as well as failure to attain the desired project objectives for example the Solyndra ( $\$ 535$ million), Beacon Power ( $\$ 43$ million), Nevada Geothermal ( $\$ 98.5$ million), Sun power ( $\$ 1.2$ billion) and First solar ( $\$ 1.46$ billion) (Amos,J., 2010).With cost estimates established correctly, senior management have sometimes classified these costs as high thereby reducing the estimate without adjustments in a corresponding decrease in the scope of a project (Amos,J 2014).

Access to Finance Rwanda is implementing two projects in north on mobilizing Irish potato farmers on access to finance through link them to financial institutions. This research carried out on the influence of the risk transfer on project success with access to finance Rwanda as case study. 


\section{The Statement of Problem}

Contractual risk transfer is a method for the assignment of the risks. It is associated with all the contracting parties. As per the theory, the most risk can be loaded to the party who has the most control and command. Indemnity (also called 'hold harmless') clauses and insurance clauses are most popular contract clauses.

It is common practice in Rwandan agriculture sector.

The top-level authority generally transfers the risks to the general contractors. The contractors many a time become responsible to handle and controlling financing the risks. However, unfair practices to the downstream parties raise indemnity agreements, as when one subcontractor must fund liability arising at least in part from another contractor's negligence. Insurance clauses assign responsibility for purchasing certain types of insurance to the parties to the contract.

The specific business problem was that some project managers and leaders have limited information regarding financial literacy do not adequately assess the relationship between time, quality, safety, environmental impact, site disputes, and fail to manage the risk.

\section{Literature Review}

Theory on risk transfer

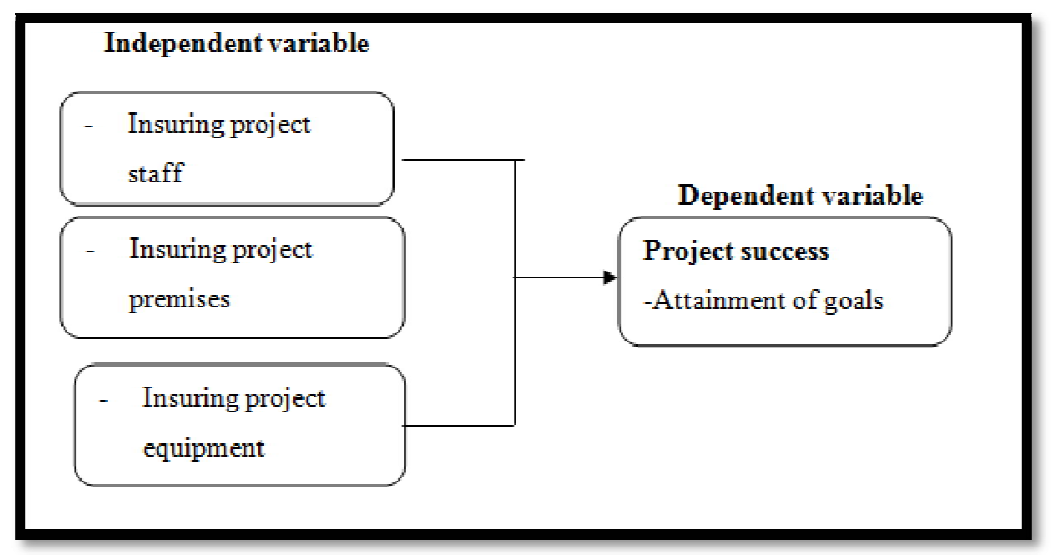

Figure 1: The Conceptual Frame Work

\subsection{Risk and Project Completion}

If another expert who has a greater capability or capacity can manage a risk, the best option is to transfer it. Michaela states that the risk should be transferred to those who know to manage it. Risks can be transferred to the client, contractor, subcontractor, designer etc., depending on the risk character. As a result, this could lead to higher costs and additional work, usually called risk premium. It must be recognized that the risk is not eliminated; it is only transferred to the party that is best able to manage it. Shifting risks and the negative effects they bring is also an option when the risks are outside project management's control, for example political issues or labor strikes (Roppel, 2011). The situation may also consist of catastrophes that are rare and unpredictable in a certain environment. Such risks that are beyond the management's control should be transferred through insurance companies.

Successful execution of a project, within the estimated budget, time and quality standards are the main duty of a project manager. Sustainability and satisfaction indicators present lower significance than the performance indicators and are more relevant to top management than for the other stakeholders (Roppel, 2011). But though time and quality might be of equal importance in the life cycle of a project, nothing can advance without the required amount of money and that requires a well-planned and estimated risk.

All project actions are strongly interwoven around project budget. The amount of required money, in most cases, dictates the duration and type of the used resources, operations and activities within the area of a project. The whole project may collapse due to project risk miscalculation, poor judgment and lack of proper oversight (Babbie, E 2018).

Some experts have suggested that customer satisfaction is a critical dimension of project success (Bakker, K.2010) argued that although the iron triangle is a traditional method. Inability to come up with deliverables of quality standards of project's products could have significant effect on your own credibility and future development as a professional. In addition, this might have a big influence on organization's reputation and have negative impact on all team members (A. Wortmann 2012) defined project efficiency as the necessary action to complete a project. (A. Wortmann 2012), opined that the iron triangle is expandable to include customer satisfaction and relationship quality as dimensions of project success.

This wrong calculation may come as result of inexperience and inefficiency in dealing with numbers and might ends up with insufficient resources. Another consequence might be the reduction in team members, or external contractors as the money simply won't be there to pay them. In such situation is very hard to avoid outcome being affected negatively (Banneman, P. L 2009).

One of the common problems a project manager may face is a poor calculation and a surplus of subsequent alterations and amendment of the project risk which are time and energy consuming. As the mantra goes, 'Time is money', and nothing is more dangerous to the successful development of a project than a badly configured risk (Capper, D. R. 2018). 
Risk can be there in the companies also where there is some difference among the projects competing for the resources. Moreover, it is well known that resources are limited.

Risk provides an evidence to justify the elimination of projects and setting priority.

Moreover, it justifies revision of its objectives to meet the demand of manageable project (Chacko, 2016).

Some of the capital costs of large projects can be spread out over time and may be financed through loans, the immediate coasts of labor and supplies usually requires dipping into the available cash. Withdrawing funds from the bank account can affect immediate liquidity, cash flow and ability to pay for other business expenses such as utilities and employee salaries (Cicmil, S. 2012).

\section{Research Methodology}

The researcher used descriptive research design, the population of this study was employees of Access to finance Rwanda project, the sample consisted of 169 randomly selected from employees of Access to finance Rwanda project with various activities, the data collection instruments for primary and secondary data from various sources included questionnaires, interviews and documentary review. The collected data was presented using tables while interpretation and analysis was done by using SPSS.

\section{Results and Findings}

This chapter presents, analyzes and interprets the result of the study in relation to the objectives. The researcher presented the collected data using tables from which percentages and frequencies were ascertained to provide a basis for analysis and interpretation.

The findings in Table4.8 revealed that $79.8 \%$ of study respondents agreed that Access to Finance Rwanda Project has insurance for project staff, 12.6 of study respondents disagreed that Access to Finance Rwanda Project has insurance for project staff while only $7.6 \%$ of respondents were undecided to the statement.

\begin{tabular}{|c|c|c|c|c|}
\hline \multicolumn{2}{|c|}{ Response } & Frequency & Percentage & Cumulative Percentage \\
\hline & Strongly Agree & 46 & 27.2 & 27.2 \\
\cline { 2 - 4 } & Agree & 93 & 55 & 82.2 \\
\cline { 2 - 4 } & Undecided & 17 & 10 & 92.2 \\
\hline & Disagree & 13 & 7.8 & 100 \\
\hline & Total & 169 & 100 & 100 \\
\hline
\end{tabular}

Table 1: Insurance for Project Premises and Equipment

The findings in Table 1 revealed that $55 \%$ of study respondents agreed that admittance to Finance Rwanda Project has cover for project site and tools, $27.2 \%$ of study respondents strongly agreed that Access to Finance Rwanda Project has cover for project site and tools, $10 \%$ of respondents was undecided while $7.8 \%$ disagreed on this issue.

\subsection{Analysis of the Effect of Risk Transfer on Performance of Access to Finance Rwanda}

\begin{tabular}{|c|c|c|c|c|}
\hline \multicolumn{2}{|c|}{ Response } & Frequency & Percentage & Cumulative Percentage \\
\hline & Strongly agree & 80 & 47.4 & 47.4 \\
\cline { 2 - 5 } & Agree & 76 & 44.9 & 92.3 \\
\cline { 2 - 5 } & Undecided & 13 & 7.7 & 100 \\
\hline & Total & 169 & 100 & 100 \\
\hline
\end{tabular}

Table 2: Standardized Materials

The study findings in Table4.10 show that $47.4 \%$ of respondents strongly agreed that Access to Finance Rwanda Project use standardized materials, $44.9 \%$ of respondents agreed that Access to Finance Rwanda Project use standardized materials and $7.7 \%$ of respondents were undecided to the statement.

\begin{tabular}{|c|c|c|c|c|}
\hline \multicolumn{2}{|c|}{ Response } & Frequency & Percentage & Cumulative Percentage \\
\hline & Strongly Agree & 88 & 52 & 52 \\
\cline { 2 - 5 } & Agree & 71 & 42 & 94 \\
\cline { 2 - 5 } & Undecided & 6 & 3.6 & 97.6 \\
\hline & Disagree & 4 & 2.4 & 100 \\
\hline & Total & 110 & 100.0 & \\
\hline
\end{tabular}

Table 3: Use of Personal Protective Equipment

The results in Table 3 revealed that $52 \%$ of respondents strongly agreed that Access to Finance Rwanda Project use personal protective equipment to ensure the health and safety of project staff, $42 \%$ of respondents agreed that Access to Finance Rwanda Project use personal protective equipment to ensure the health and safety of project staff, $3.6 \%$ were neutral while $2.4 \%$ of respondents disagreed that Access to Finance Rwanda Project use personal protective equipment to ensure the health and safety of project staff. 
According to Table 4, there is positive relationship between two variables where by $\mathrm{r}=.895$ this indicates risk transfer had positive impact on project success at access to finance Rwanda, the success of projects depend on risk mitigation. Whereby risk transfer is independent variables and project success is dependent variables.

\begin{tabular}{|c|c|c|c|}
\hline \multicolumn{3}{|c|}{ Correlations } \\
\hline \multirow{3}{*}{ Risk transfer } & $\begin{array}{c}\text { Pearson } \\
\text { Correlation }\end{array}$ & Risk Transfer & Insurance \\
\cline { 2 - 4 } & Sig. (2-tailed) & 1 & .895 \\
\cline { 2 - 4 } & $\mathrm{N}$ & 43 & 434 \\
\hline \multirow{4}{*}{$\begin{array}{c}\text { Project } \\
\text { Performance }\end{array}$} & $\begin{array}{c}\text { Pearson } \\
\text { Correlation }\end{array}$ & .895 & 1 \\
\cline { 2 - 4 } & Sig. (2-tailed) & .544 & 43 \\
\cline { 2 - 4 } & $\mathrm{N}$ & 43 & \\
\hline
\end{tabular}

Table 4: The Relationship between Budget and Success of Projects

\section{Discussion}

\subsection{Conclusion and Recommendation}

Based on the information drawn from findings the researcher concluded that insuring project staff has a positive and high effect on performance of Access to Finance Rwanda.

Admittance to Finance Rwanda getting affected by the insuring premises.

Finally, the researcher found a negative association between risk transfer and performance of Access to Finance Rwanda.

\subsection{Recommendations}

Admittance to finance Rwanda project should carry on managing risk administration matter sound since it is imperative in nurturing success.

\section{To the Government}

The government of the Republic of Rwanda should help projects to improve their success through capacity building trainings in managing budget.

\section{Areas for Future Research}

The researcher suggested the following areas as necessary for future research in relation to risk management and its effects on project performance, research should be carried out on the contribution of risk management on project implementation and research should also be carried out on the contribution of risk management on project resource utilization. The researcher suggested that in future research should be carried out on the benefits of risk management on attainment of project objectives.

\section{References}

i. Addison, W. \& Vallabh, P. (2012) Effect of project risk Identification performance of software projects in IT enterprises in China. Journal of Project Risk Management, Vol. 8 No 1, pp. 17-24.

ii. Addison, W. \& Vallabh, P. (2012) Effect of project risk Identification performance of software projects in IT enterprises in China. Journal of Project Risk Management, Vol. 8 No 1, pp. 17-24.

iii. Akintoye, A. S. \& Macleod, M.j. (2017), Risk analysis and management in Construction.

iv. International Journal of Project Management, Vol. 15 No 1, pp. 1-38.

v. Amos, J. \& Dents, P. (2010). Risk analysis and management for major construction projects. Proceedings: RICS COBRA Conference. Portsmouth, September, 1-35.

vi. Babbie, E. (2018). The Survey of Social Research: Belmont. California. €Bakker, K. De, Boonstra, Michaela Slovin. (2011), Risk managements' communicative effects influencing IT project success. International Journal of Project Management Vol. 30

vii. Bakker, K. DE, Boonstra, A., Wortmann, H. (2010), Does risk management contribute to IT project success? A meta-analysis of empirical evidence.

viii. A.D.F. (2010). Modelling global risk factors affecting construction cost performance.

ix. International Journal of Project Management, 21(4): 261-269.

x. World Bank. (2011). Risk and risk management in software projects: A reassessment. The Journal of Systems and Software, 81(12), 2118-2133. Bunni, N.G

xi. Rappel. (2011). Overview of risk in construction. In J. Uff and A.M. Odams (2015). Risk Management and Procurement. London: The Cromwell Press, 11-25.

xii. Chacko, G. \& Harris, G. (2016). Information and Communication Technology and Small, Medium and Micro Enterprises in Asia-Pacific - size does not matter. Information Technology for Development, 12(2): $175-177$.

xiii. Chandran, E. (2014). Research Methods a quantitative approach. Kenya: Starbright service Ltd

xiv. Cicmil, S., Cooke-Davies, T., Crawford, L., \& Richardson, K. (2014). Complexity and the paradox of project control, in: Proceedings of the 9 th IRNOP conference, Berlin Germany, October 11-13. 
xv. Clark, R.C., Pledger, M., \& Needler, H.m.j. (1990), Risk analysis in the evaluation of non-aerospace projects. Risk Management, Vol. 8 No 1, pp. 17-24. DOD 5000

xvi. Cleland, D.I. \& Ireland, L.R. (2012), Project Management: Strategic Design and Implementation, McGraw Hill, Boston, MA.

xvii. De Bakker K., Boonstra A., \& Wortmann H. (2010). Does risk management contribute to IT

xviii. Project success? A meta-analysis of empirical evidence. Fellow, R. \& Liu, A. (2013). Research Methods for Construction. 2nd Ed. Oxford: Blackwell.

xix. Flanagan, R. and Norman, G. (2013). Risk Management and Construction. Oxford: Blackwell. Godfrey, P. (2015). The control of risk. In J. Uff and A.M. Odams

xx. Han, R. \& Huang, G. (2017), An empirical Analysis of Risk Assessment and Performance on software projects. Project Management Journal, Vol. 37 No 3, pp. 37-48. He, Z.

xxi. Adam, E. and P.M. Swamidass. (2013). Assessing Operations Management from a Strategic Perspective. Journal of Management: p 181-203. 